\title{
TEORIAS DA CIDADE
}

\author{
Magda de Lima Lúcio*
}

FREITAG, Bárbara. Teorias da cidade. Campinas (SP): Papirus, 2006. 192p.

A autora é alemã, tendo migrado para o Brasil com a família logo após o fim da Segunda Guerra, em 1948. Retornou ao país natal para freqüentar os cursos de graduação e pós-graduação. $\mathrm{Na}$ Universidade Livre de Berlim cursou a graduação, o mestrado e o pós-doutorado; na Universidade Técnica de Berlim, o doutorado. Atualmente é professora associada do Departamento de Sociologia da Universidade de Brasília e coordena um Programa de Pesquisa do Conselho Nacional de Desenvolvimento Científico e Tecnológico (CNPq) intitulado "Capitais migrantes, poderes peregrinos, representações nômades". Tem mais de 20 livros publicados, sendo três especificamente voltados para a elaboração de uma análise sobre a questão urbana: Cidade dos homens (2002), Itinerâncias urbanas (2004), no qual apresenta artigos relacionados ao desenvolvimento do programa de pesquisa homônimo; e Teoria das cidades (2006).

A construção de uma teoria das cidades capaz de constituir hábeis caminhos reflexivos para a entendimento do fenômeno urbano, em toda a sua extensão, é o intento sobre o qual a última obra se estrutura. O percurso analítico se elabora pela investigação do fenômeno sob diferentes escolas. Nesse livro o termo "escola" é

* Doutora em Sociologia.E-mail: magda@unb.br 
tomado como um conjunto de teóricos que pensam a questão urbana e o fenômeno das cidades no contexto de suas culturas, de seu tempo, de suas tradições filosóficas e sociológicas. Cada "escola" analisada pressupõe um pensamento que pode ser expresso em uma teoria mais ou menos convergente, de tal forma que pode ser compreendida por pensadores de outra escola.

O livro encontra espaço privilegiado na seara da Sociologia Urbana em virtude do acelerado processo de urbanização mundial que levou, em 2006, em escala planetária, à superação da população rural, pela primeira vez na história, pela população urbana. Esse ritmo veloz de migração do campo em direção às cidades tem alavancado a concentração de pessoas em espaços urbanos, muitas vezes, saturados, o que fomenta a afluência de problemas sociais. Essa sistemática de ocupação urbana não é recente, pois alguns estudiosos alertavam para a questão já na década de 60 . Esses problemas são atribuídos em sua maior parte ao rápido e intenso processo de urbanização de países periféricos, processo esse caracterizado pelo aumento da desigualdade social e do crescente desamparo de grupos sociais cada vez mais significativos.

Em obra anterior (Cidade dos homens. Rio de Janeiro: Tempo Brasileiro, 2002) e em outros trabalhos, inscritos em outros temas, a autora apresenta o conceito de megalópole como uma possibilidade compreensiva para esse fenômeno. Esse conceito faz parte de uma arquitetura analítica onde um tipo específico de urbanização ocorrido na segunda metade do século XX propicia a emersão de cidades de países do Hemisfério Sul como espaços empobrecidos de tipos sociais, em particular mulheres, crianças, idosos e deficientes, dentre outros. Esse empobrecimento se apresenta como face visível do ajuste estrutural em nível mundial, trazendo como conseqüência o acentuamento da vulnerabilidade social de alguns grupos. 
Algumas cidades do Hemisfério Sul são citadas como exemplos de transformação de metrópole em megalópole, como São Paulo. O critério basilar para essa caracterização é o "crescimento descontrolado, desregrado da população urbana, que faz transbordar os limites naturais e administrativos da cidade, tornando-a insustentável" (p. 153). Esse crescimento é acompanhado de um decréscimo da qualidade de vida e de um alto comprometimento ambiental.

Diante dessa paisagem urbana, o estabelecimento de "teorias da cidade" pretende demonstrar o esforço de conceituação do espaço citadino como um fenômeno universal da vida em sociedade. Esse vigoroso processo se realiza na Sociologia por meio do entendimento e de eventuais explicações para o fenômeno urbano enquanto lugar onde a vida surge permeada pelos conflitos, ansiedades e desejos. A análise da subjetividade não abrange integralmente o estudo acerca da vida citadina, pelo contrário, outros elementos a compõem e a transformam, a saber, as intervenções urbanas, a revitalização de determinados espaços em detrimento de outros, a definição estratégica dos investimentos públicos e privados no ambiente urbano, a criação e consolidação de espaços públicos, o modelo de organização política de determinada sociedade, enfim, a análise dos processos econômicos nacionais e internacionais que produzem inflexões nas cidades e em seus habitantes.

Esses elementos perpassam e se estruturam ao longo do livro enfatizando diversos moldes analíticos, com ênfase para produções alemãs, francesas, inglesas e estadunidenses. A análise teórica a partir de construções datadas e fixadas temporal e culturalmente apresentam um modo consciente de compreensão fundado no preceito de que esses estudos representam a herança que possuímos para construir uma análise sociológica do momento em que vivemos. 
Essa estratégia enseja vislumbrar teoricamente a cidade como um fenômeno em constante construção, passível de ser interpretado por meio de sua cultura e tradição teórica. Tendo os alemães como pioneiros na análise do tema das cidades, constata-se sua influência nos trabalhos de teóricos norte-americanos, como é o caso de Robert Park, um dos fundadores da Escola de Chicago, ex-aluno de Walter Benjamin. E, por seu turno, o pensamento da Escola de Chicago provoca influência na produção de sociólogos franceses, dentre eles, Maurice Halbwachs, Alain Touraine e Henri Lefèbvre.

Segundo a autora, as "escolas" produziram forte influência também no pensamento de vários teóricos da cidade, arquitetos e urbanistas brasileiros. O livro se referencia em estudos extramuros para verificar o grau dessa influência na construção do pensamento brasileiro nacional, e encontra duas grandes linhas analíticas: a repercussão do pensamento internacional no pensamento urbano brasileiro; e a receptividade dessa produção, sua modificação e realização no contexto nacional. Como exemplo da recepção das teorias e as transformações urbanas por elas inspiradas ocorridas no país, pode-se citar, a reforma na cidade de Santos, em São Paulo, uma espécie de "hausmanização" da cidade (traçando uma analogia reveladora com a remodelagem empreendida em Paris, entre 1853-1870, pelo então planejador urbano e prefeito da cidade, Barão de Haussman) atribuindo semelhança à remodelagem urbana empreendida em Paris. Assim como a Cidade Luz, a cidade de Santos passou por drenagem das águas, construção de canais e saneamento de territórios alagados. A partir dessa reforma, a cidade adquiriu uma nova função socioeconômica, deixando de ser conhecida como a cidade com o maior porto do país, para ser referência também em turismo de veraneio.

A leitura do livro apresenta, mesmo ao leitor mais leigo em questões urbanas, um panorama instigante do tema cidades, 
entremeado por fios teóricos que se emaranham. No seu conjunto, o livro reflete a rica trajetória da socióloga. As marcas de seus itinerários se incorporam às conexões estabelecidas entre autores, correntes e escolas. O convite que nos é feito no fim de sua introdução não surge como retórica ou mera formalidade. Emerge como oportunidade fecunda de embarcarmos em uma longa viagem que, aos poucos, se transforma em uma fluida e suave flânerie pelas ruínas, pelos edifícios suntuosos, pelos monumentos, praças e ruas, tendo como bússola as teorias da cidade. 